\title{
The Problem of Imminence in an Uncertain World Noam Lubell*
}

Final draft, to be published in M. Weller (ed) The Oxford Handbook of the Use of Force in International Law (OUP, forthcoming 2014)

\section{Introduction}

Almost any discussion of self-defence under international law inevitably includes the debate over anticipatory self-defence. This is true not only in modern writings, but also throughout the centuries of legal and philosophical examinations of the matter. Most arguments supporting anticipatory action invariably turn at some point to requiring a criterion of imminence, whether stating it specifically, or in another guise. Whether or not anticipatory self-defence should be allowed is a question that encompasses numerous legal, moral, and political conundrums. The current examination does not aim to resolve the wider debate on anticipatory self-debate. Rather, it focuses on one particular and crucial component of the debate: the concept of imminence. The following examination proceeds, therefore, on the assumption that anticipatory self-defence may be a legitimate option for action. Based on this premise, it sets out to analyse the meaning of imminence in this context, how it is to be interpreted, what it might justify and what it might exclude, and whether it is in fact a criterion that can be upheld in light of modern challenges.

\section{The requirement of imminence}

The requirement of imminence can be traced back to early discussions of anticipatory selfdefence. Hugo Grotius recognised the need to include a restriction of this kind, noting that "[t]he danger must be immediate, which is one necessary point." 1 The incident of the Caroline, just over two centuries later, has become a seminal reference point for the requirement of imminence, and continues to be turned to in modern discussion and debate. ${ }^{2}$ This revolved around circumstances in 1837 during which the British and US governments

\footnotetext{
* Professor of Law, School of Law, University of Essex, UK. Thanks are due to Charlotte Pier for her research assistance.

${ }^{1}$ Hugo Grotius On the Law of War and Peace De Jure Belli ac Pacis, Translated by A. C. Campbell, London, 1814, Book II, Chapter 1, V.

${ }^{2}$ For example, the UK Attorney General traced the customary international law definition of self-defence to the Caroline, when noting that this definition "included the right to use force in anticipation of an imminent armed attack". Lord Goldsmith, Attorney General of the UK, House of Lords, 21 April 2004. Hansard, 21 April 2004, column 370; see also "Judgement, Part 18, The Invasion of Denmark and Norway: Conclusion", in Trial of the Major War Criminals before the International Military Tribunal. Volume I: Official Documents. [Official text in the English language.] Nuremberg: IMT, 1947. pp. 206-209.
} 
exchanged correspondence over the legality of action taken by the UK, which included British forces forcibly boarding a ship (the Caroline), said to be supplying Canadian rebels, setting it on fire and sending it over the Niagara Falls. ${ }^{3}$ The following is quoted from this exchange:

"Undoubtedly it is just, that while it is admitted that exceptions growing out of the great law of self-defence do exist, those exceptions should be confined to cases in which the "necessity of that self-defence is instant, overwhelming, and leaving no choice of means, and no moment for deliberation."",4

The customary right to anticipatory self-defence, which many trace back to the Caroline, came under challenge with the emergence of the United Nations Charter. When the provision on self-defence in Article 51 of the Charter was drafted, the possibility for anticipatory selfdefence appeared to have been excluded, by only allowing for a right of self-defence if "an armed attack occurs". However, even in the process of this act of exclusion, imminence remained at the forefront of discussion. In the ensuing debates, the centrality of imminence to any justification of anticipatory self-defence was reflected in the arguments of both detractors and supporters of such action. Kunz, for example, noted in 1947, "[t]he "imminent" armed attack does not suffice under Art. 51". ${ }^{5}$ Bowett, conversely, stated that "[i]t is not believed, therefore, that Art. 51 restricts the traditional right of self-defence so as to exclude action taken against an imminent danger but before 'an armed attack occurs'." 6

While it is the UN Charter's apparent renunciation of anticipatory self-defence which supplies the opponents of such action with their most potent ammunition, it is also through developments under the UN auspices which provide support for a limited form of anticipatory self-defence. The 2004 Report of the Secretary General's High-level Panel on Threats, Challenges and Change declared that:

"a threatened State, according to long established international law, can take military action as long as the threatened attack is imminent, no other means would deflect it

\footnotetext{
${ }^{3}$ Robert Jennings "The Caroline and McLeod Cases" 32 American Journal of International Law (1938) 82.

${ }^{4}$ Letter from Mr. Webster to Lord Ashburton, Department of State, Washington, 6th August, 1842, text available on http://www.yale.edu/lawweb/avalon/diplomacy/britain/br-1842d.htm.

5 Josef Kunz "Individual and collective Self-Defense in Article 51 of the Charter of the United Nations" American Journal of International Law, Editorial Comment p.872 (1947), p.878.

${ }^{6}$ Derek Bowett Self-Defence in International Law (Manchester, Manchester University Press, 1958), pp.191192.
} 
and the action is proportionate. The problem arises where the threat in question is not imminent but still claimed to be real."7

Notably, once again the key criterion and primary restriction imposed on anticipatory selfdefence, is that it can only be launched against an imminent attack. Imminence appears here as an additional requirement, on top of necessity (stated in the above quotation as "no other means would deflect it") and proportionality. The latter two criteria are considered fundamental to legitimising any claim of self-defence, ${ }^{8}$ not only anticipatory action. Imminence, however, is less relevant when dealing with an existing armed attack that has already occurred or is ongoing. By definition, it relates to a future event. It therefore comes into play once we begin considering anticipatory self-defence. It is traditionally used as a temporal description, ${ }^{9}$ pointing to a specific impending attack. ${ }^{10}$ The imminence of the said attack can present a useful test when measuring the necessity and proportionality of any selfdefence action. ${ }^{11}$ Imminence can therefore be described as a third requirement, in addition to necessity and proportionality. ${ }^{12}$ It remains separate from necessity: an armed attack may be imminent, but self-defence is not necessary because there are non-forcible alternatives to prevent it striking the state or due to the Security Council already mobilising to preclude the need for self-defence action. Conversely, and controversially, one might argue that there is necessity to take action in self-defence against a future attack that is not imminent. The latter argument is at the heart of some of the more contentious areas of anticipatory self-defence. ${ }^{13}$

The practice of states and views of commentators clearly demonstrate that the presence of imminence will often be a major factor in their position on anticipatory action. This is true both with regard to the general position taken on this issue as a matter of law, as well as the

\footnotetext{
7 “A More Secure World: Our Shared Responsibility” Report of the Secretary General's High-level Panel on Threats, Challenges and Change UN 2004, para.188. The given example of not imminent is "for example the acquisition, with allegedly hostile intent, of nuclear weapons- making capability"; See also "Imminent threats are fully covered by Article 51, which safeguards the inherent right of sovereign States to defend themselves against armed attack. Lawyers have long recognized that this covers an imminent attack as well as one that has already happened." In Larger Freedom: Towards Development, Security and Human Rights for All, Report of the Secretary-General, delivered to the General Assembly, UN Doc.A/59/2005 (21 March 2005), para124.

${ }^{8}$ Case Concerning Military and Paramilitary Activities in and Against Nicaragua, [1986] I.C.J.Rep. 14, para.194; Oil Platforms (Islamic Republic of Iran v. United States of America) Reports1993, para.51; Legality of the Threat or Use of Nuclear Weapons, Advisory opinion, 8 July 1996, ICJ Reports 1996, paras.41-43.

${ }^{9}$ Onder Bakircioglu, Self-Defence in International and Criminal Law: the Doctrine of Imminence (Routledge, 2011) p.196; but see next section on modern threats for an examination of the viability of the temporal aspect.

${ }^{10}$ See section on meaning of imminence, infra.

${ }^{11}$ Bakircioglu, supra, n.9, p.213.

${ }^{12}$ The UK Attorney General, after discussing the imminence requirement, proceeds to discuss the "[t]wo further conditions" of necessity and proportionality, supra, n.2.

${ }^{13}$ See section on modern challenges, infra.
} 
reaction to particular events. The Independent International Fact-Finding Mission on the Conflict in Georgia provides some of the most recent examples of the relevance of imminence in the views of states. ${ }^{14}$ The Georgian government noted that in the absence of an imminent attack by Georgia, Russia had no right to self-defence; ${ }^{15}$ the Russian argument included the alleged danger of an imminent attack by Georgia on Abkhazia. ${ }^{16}$

Two of the most commonly referred to cases in the debates over anticipatory self-defence have involved the state of Israel, and the criterion of imminence was central to them both. While there are differing interpretations of the events and positions surrounding the 1967 Israeli-Arab war, ${ }^{17}$ it has been argued that most of the international community perceived this as a case of self-defence taken in the face of an imminent attack, and consequently viewed it as an acceptable course of action. ${ }^{18}$ Conversely, Israel's attack on the Iraqi nuclear reactor in 1981 was condemned due to the lack of an imminent threat. ${ }^{19}$ Tellingly, in an exchange at the Security Council, after the Israeli representative cited the position of Sir Humphrey Waldock as support for anticipatory action, the Iraqi representative responded by pointing out that the Israeli quotation had conveniently left out Waldock's reference to the anticipated attack being imminent. ${ }^{20}$ The International Court of Justice has refrained from taking an explicit position on anticipatory self-defence. ${ }^{21}$ However, the International Military Tribunal at Nuremberg relied on the Caroline formula, ruling that Germany's invasion of Norway was not taken in the face of an imminent Allied landing. ${ }^{22}$ The requirement of imminence arises not only in relation to specific cases, but also as a general rule. According to the UK Attorney General: "[I]t has been the consistent position of successive United Kingdom Governments over many

\footnotetext{
${ }^{14}$ Independent International Fact-Finding Mission on the Conflict in Georgia, September 2009, Volume II, available at http://www.ceiig.ch/Report.html

15 Ibid, para. 186.

${ }^{16} \mathrm{Ibid}$, para.222; Abkhazia also claimed to have a right of self-defence against an imminent Georgian attack, para.292.

${ }^{17}$ Compare, for example: Thomas Franck Recourse to Force: State Action Against Threats and Armed Attacks (Cambridge University Press, 2002) pp.101-105; Christine Gray International Law and the Use of Force (Oxford University Press, 2008), p.161.

${ }^{18}$ Franck, ibid.

${ }^{19}$ As noted by the UK at the time, "[t]here was no instant or overwhelming necessity for self-defence" 20 International Legal Materials 970 (1981), paras.199-201.

${ }^{20}$ Security Council Official Records, Thirty-Sixth Year, 2288th Meeting, UN Doc. S/PV.2288, 19 June 1981.

21 "[... the issue of the lawfulness of a response to the imminent threat of armed attack has not been raised. Accordingly the Court expresses no view on that issue." ICJ Nicaragua, para.194; this was later repeated in Case Concerning Armed Activities on the Territory of the Congo (Democratic Republic of the Congo $v$. Uganda), "So it is in the present case." para.143.

${ }^{22}$ Nuremberg IMT, supra, n.2, pp. 206-209.
} 
years that the right of self-defence under international law includes the right to use force where an armed attack is imminent." 23

As for the community of legal commentators, while they continue to be engaged in a debate that has persisted for decades over the legitimacy of anticipatory self-defence - and it is difficult to pinpoint a majority of opinion either way at any given time - there does appear to be a growing number of views that support pre-emptive action when limited to imminent attacks. ${ }^{24}$ Even while presenting the lack of agreement and the critique of anticipatory selfdefence, the majority of opinion does note that if anticipatory self-defence were to be accepted, then it must only be in relation to imminent attacks. ${ }^{25}$

There are many reasons to consider anticipatory self-defence as unlawful, regardless of impending attacks, and to maintain a strict requirement that self-defence can only take place after an attack has occurred. ${ }^{26}$ Indeed, the legal, textual, ethical and political cases against any form of anticipatory self-defence all have merit. Notwithstanding, it is equally clear that there is also support for the argument that a state facing an impending devastating attack cannot be expected to have to wait for it to actually strike its cities before engaging in forcible selfdefence. Arguments for anticipatory self-defence of some form or another have been continuously presented by both commentators and states. ${ }^{27}$ As seen above, the requirement of imminence is a common theme running through most of these arguments and is, in fact, often the key factor upon which the legitimacy of such action will turn. Assuming that we wish to accept a right to anticipatory self-defence, the requirement of imminence demands further clarification.

\section{The meaning of imminence}

The plain English language definition of "imminent" reveals some of the difficulties that arise in the legal interpretation in the context of self-defence. Note the differences between

\footnotetext{
${ }^{23}$ Attorney General of the UK, supra, n.2.

${ }^{24}$ High Level Panel, supra, n.7; Secretary General, supra, n.7; Attorney General, infra, n.33; "The Chatham House Principles of International Law on the Use of Force by States in Self-Defence" 55 International and Comparative Law Quarterly963 2006, p.965; Bowett, supra, n.6; Christopher Greenwood, Vaughan Lowe, Philippe Sands, Michael Wood, all in Elizabeth Wilmshurst, Principles of International Law on the Use of Force by States in Self-Defence - working paper, The Royal Institute of International Affairs, October 2005; see also analysis of views in Tom. Ruys Armed Attack and Article 51 of the UN Charter (Cambridge University Press, 2010) pp.324-342.

${ }^{25}$ See analysis in Fact-Finding Mission on Georgia, supra, n.14, 254-256; For an examination, and critique, of anticipatory self-defence, see Gray, supra, n.17,pp.160-166, 212.

${ }^{26}$ See general discussion of anticipatory self-defence, $i b i d$.

${ }^{27}$ Supra, n.24.
} 
the following definitions: according to the Oxford dictionary an imminent event is one which is "about to happen". ${ }^{28}$ The Cambridge dictionary defines it as "coming or likely to happen very soon", ${ }^{29}$ According to the Merriam-Webster dictionary it is an event which is "ready to take place" or "hanging threateningly over one's head". ${ }^{30}$ Most strikingly, the first of these might be read as describing a definite impending event, while the second definition introduces the notion of "likely" - that is not definite and might not occur - and the third definition remains equivocal, since something that is "ready to take place" tells us nothing as to the certainty or timing of its future occurrence. When attempting to implement the requirement for imminence in practice, both the temporal aspect and the gap between certainty and likelihood, prove to be the primary areas of debate and concern.

The imminence criterion is a regular feature in discussions of anticipatory self-defence, and is usually presented as a requirement for legitimising the action. However, setting aside the dictionary definition, there is no legal definition of this notion. There are, nonetheless, certain characteristics that can be deduced from state practice, cases, and commentators' opinions. Two particular elements repeatedly found in this context, are the temporal aspect of imminence as referring to an immediate threat; and the requirement that the threat be specific and identifiable.

The temporal aspect was already evident in the early treatment of the subject by Grotius, who required the danger to be "immediate". ${ }^{31}$ This immediacy of the threat is also apparent in the treatment of the subject by a large number of commentators. ${ }^{32}$ State practice provides further evidence for such an approach, which differentiates between potentially legitimate anticipatory self-defence, as opposed to the vaguer notion of preventive self-defence against threats further into the future. ${ }^{33}$ Indeed, when force was used in circumstances perceived as lacking an immediate threat, this has led to condemnation. ${ }^{34}$ This apparent correlation

\footnotetext{
${ }^{28} \mathrm{http} / / /$ oxforddictionaries.com/definition/english/imminent?region=uk\&q=imminent

${ }^{29} \mathrm{http} / / /$ dictionary.cambridge.org/dictionary/british/imminent?q=imminent

${ }^{30} \mathrm{http}: / /$ www.merriam-webster.com/dictionary/imminent

${ }^{31}$ Grotius, supra, n.1, Chapter 1, V.

${ }^{32}$ See analysis of views by Fact-Finding Mission on Georgia, supra, n.14, paras.254-256; see analysis of views in Ruys supra, n.24, pp.322-324.

33 "It is therefore the Government's view that international law permits the use of force in self-defence against an imminent attack but does not authorise the use of force to mount a pre-emptive strike against a threat that is more remote." Attorney General of the UK, supra, n.2; IMT, infra, n.34; Condemnation of Israeli strike, infra, n. 34,71; see also supra, n.14-22 and accompanying text.

${ }^{34}$ The UK condemned the Israeli attack on the Iraqi nuclear reactor, since "[t]here was no instant or overwhelming necessity for self-defence" 20 International Legal Materials 970 (1981); German action was unjustified since "they were not made for the purpose of forestalling an imminent Allied landing, but, at the most, that they might prevent an Allied occupation at some future date." Nuremberg IMT, supra, n.2, pp. 206-
} 
between imminence and an immediate threat notwithstanding, in the Case Concerning the Gabcikovo-Nagymaros Project, the ICJ appeared to take a slightly different approach to imminence, noting:

"'Imminence" is synonymous with "immediacy" or "proximity" and goes far beyond the concept of "possibility". As the International Law Commission emphasised in its commentary, the "extremely grave and imminent" peril must "have been a threat to the interest at the actual time" [...]. That does not exclude, in the view of the Court, that a "peril" appearing in the long term might be held to be "imminent" as soon as it is established, at the relevant point in time, that the realisation of that peril, however far off it might be, is not thereby any less certain and inevitable." ${ }^{35}$

While this might appear to delink the notion of imminence from immediacy, it must also be read in context: the case was not one of self-defence and use of force, and the Court might therefore have felt less concerned over taking a more lax interpretation of imminence. Furthermore, the case dealt with an environmental threat subjected to scientific standards, rather than guessing future political and military intentions of another party. ${ }^{36}$ As will be seen in a later section, the inability to achieve certainty in the prediction of future attacks is a key factor in the assessment of imminence. Moreover, this statement by the Court also highlights the second characteristic of imminence: that it is in relation to a specific and identifiable threat.

While the ICJ has not explicitly ruled on anticipatory self-defence, it has declared that selfdefence cannot be taken in order to "protect perceived security interests" outside of Article 51 of the Charter. ${ }^{37}$ The notion of imminence requires a specific anticipated attack. This must go beyond vague suspicions, ${ }^{38}$ and requires a threat of an identifiable actual attack which is being prepared, rather than the unformed potential of attack, ${ }^{39}$ or a threat which has not yet

209; contrast these cases with the 1967 Israeli-Arab war, in relation to which it has been argued that Israel was taking action to prevent what was perceived as an imminent attack about to occur, and that most of the international community even if not explicitly endorsing, did view this as acceptable action. Franck, supra, n.17, 101-105.

${ }^{35}$ Case Concerning the Gabcikovo-Nagymaros Project (Hungary/Slovakia), 1997 I.C.J. 7, para.54.

${ }^{36}$ See later sections on certainty, and last window of opportunity; see view on the factual approach to imminence, in Constantine Antonopoulos "Force by Armed Groups as Armed Attack and the Broadening of Self-Defence" 55 Netherlands International Law Review 159 (2008), p.177.

${ }^{37}$ ICJ DRC Uganda, para.148.

${ }^{38}$ Emer de Vattel The Law of Nations, from The New Edition, by Joseph Chitty( Philadelphia: Johnson \& Co.1883). Book II, Ch.IV,50.

${ }^{39}$ Note the differentiation made in the Report of the UN Secretary General, between an imminent attack for which anticipatory self-defence is supported, as opposed to a latent threat. Supra, n.7. paras.124-125. 
materialised. ${ }^{40}$ There must be a "concrete danger of an imminent attack" which is "objectively verifiable", ${ }^{41}$ and there is wide agreement by states and writers that force in selfdefence cannot be taken to counter "potential or abstract" threats. ${ }^{42}$

These characteristics of imminence are linked to the concept of 'interceptive self-defence'. ${ }^{43}$ The use of the word 'interceptive' suggests circumstances in which the incoming attack is a definite occurrence - indeed it may have already begun - and the state is able, in the nick of time, to step in and stop it before the damage is done. This is an enticing proposition for a solution which some may view as bridging the gap between an attack that has already occurred, and a future one which may or may not take place. At closer examination, it is however unclear whether this concept in fact clarifies the situation. Interception can be presented in one of two ways: either as referring to an armed attack which is physically occurring and cannot be undone, and in which we are speaking of circumstances such as intercepting rockets in flight; ${ }^{44}$ or as referring to situations in which the opposing state has "embarked upon an apparently irreversible course of action" 45 such as sending troops towards the border. This juxtaposition means that we are, in fact, back to the starting point. There are only two possibilities: either the attack has begun and is occurring, in which case self-defence can take place under the strict requirements of Article 51; or, however "apparently irreversible" it might seem, it has not physically begun and there is at least a theoretical chance of it never occurring (e.g. troops can be called back before crossing the border), in which case we are in the familiar territory of anticipatory self-defence. The concept revolves around the possibility of defining the occurrence of an armed attack based on when it begins, rather than when the effect of the first strike is experienced. ${ }^{46}$ But once we are willing to consider that an attack has begun even in situations in which it can conceivably be stopped before it actually affects the target state, then we are back to asking the same questions that arise in the context of anticipatory self-defence. Interceptive self-defence is not therefore a 'third way' between strict non-anticipatory and anticipatory self-defence;

\footnotetext{
${ }^{40}$ Chatham House Principles, supra, n.24, p.968.

${ }^{41}$ Fact-Finding Mission on Georgia, supra, n.14, paras.254-256.

${ }^{42}$ Ibid.

${ }^{43}$ Yoram Dinstein, War, Aggression, and Self-Defence (Cambridge, Cambridge University Press, 2012), p.203; See also discussion of possibility of intercepting rockets in flight, in Ian Brownlie, International Law and the Use of Force by States (Oxford University Press, 1963), p.367-368.

${ }^{44}$ Brownlie, ibid.

${ }^{45}$ Dinstein, supra, n.43, p.204. emphasis added.

46 "The crux of the issue, therefore, is not who fired the first shot but who embarked upon an apparently irreversible course of action, thereby crossing the legal Rubicon. The casting of the die, rather than the actual opening of fire, is what starts the armed attack." Dinstein, supra, n.43, p.204.
} 
depending on how one presents the notion, it is either part of the former or the latter. It can, on the one hand, be understood as pointing to the possibility of considering an armed attack to have occurred from the first moment a truly irreversible act has taken place (e.g. missiles are in flight and cannot be aborted), even if the strike has not yet been felt. ${ }^{47}$ If imminence would thereby be equated with this interpretation of interceptive action, the imminence criterion would itself be redundant, since it would be understood as covering only those cases in which the armed attack is already occurring; as such it can fit well within the framework of Article 51. On the other hand, interceptive action could be understood as allowing for selfdefence from the moment it seems that the other party has decided to attack and has begun taking steps to put the attack in place, and it appears inevitable from their actions that the attack will happen (e.g. the opposing state is amassing troops and moving them within its own territory toward the border). Since the attack has not yet materialised and could still be reversed with no harm, this interpretation is in fact a form of anticipatory self-defence. It is, however, one which adheres to as strict and narrow a requirement of imminence as can be, and would meet most tests for reasonable assumptions of an impending attack. Adhering to this and judging whether the attack is indeed inevitable, will ultimately require a process of judgement and reliance on certain indicators and proof, as will be discussed in a later section.

\section{Imminence and modern threats}

The pre-emption doctrine advanced by the US during the Bush (G.W.) presidency, expanded the notion of anticipatory self-defence into a policy advocating preventive action to counter a range of future threats, noting the particular threats posed by weapons of mass destruction (WMD) and terrorism. According to the US National Security Strategy of 2002:

"For centuries, international law recognised that nations need not suffer an attack before they can lawfully take action to defend themselves against forces that present an imminent danger of attack. Legal scholars and international jurists often conditioned the legitimacy of preemption on the existence of an imminent threat-most often a visible mobilisation of armies, navies, and air forces preparing to attack. We must adapt the concept of imminent threat to the capabilities and objectives of today's adversaries. Rogue states and terrorists do not seek to attack us using conventional

\footnotetext{
${ }^{47}$ Whether and how far the notion of armed attack can be stretched in this manner will remain questionable. In a related context, Gray notes that "[i]n practice states prefer to argue for an extended interpretation of armed attack and to avoid the fundamental doctrine debate". Gray, supra, n.17, p.165.
} 
means. They know such attacks would fail. Instead, they rely on acts of terror and, potentially, the use of weapons of mass destruction [...]."48

In 2006 the UK Secretary of State for Defence at the time, explicitly linked these threats to the debates over the concept of imminence, stating that: "Another specific area of international law we perhaps need to think more about is whether the concept of imminence i.e. the circumstances when a state can act in self-defence without waiting for an attack - is sufficiently well developed to take account of the new threats faced."49 Other state representatives, as well as commentators, have also pointed to a perceived need to interpret the concept of imminence in light of terrorism, WMD, and modern threats more generally. ${ }^{50}$ But, what is it about these specific threats, that ignites the desire to rethink - and possibly bring into question - the notion of imminence, which as demonstrated earlier has been established as a fundamental component in the theories of anticipatory self-defence? To answer this, it is necessary to first distinguish between two different threats mentioned in the above, and recognise the distinct challenges they present.

The threat of terrorism is rooted in the unpredictability of its source. The concept of terrorism, however, lacks a commonly agreed or legally adopted definition, and its selective use and frame of reference, are often the subject of controversy. ${ }^{51}$ In the context of selfdefence, one of the main issues at stake is the preliminary question as to the possibility for a state to invoke the right to self- defence following an attack by a non-state actor operating from outside its borders, and which cannot be attributed to another state. ${ }^{52}$ Assuming that self-defence may arise in the context of non-state actors, we must proceed to inquire as to

\footnotetext{
${ }^{48}$ The National Security Strategy of the United States of America, The White House, September 2002, p.15.

${ }^{49}$ Reid addresses RUSI on "20th-Century Rules, 21st-Century Conflict", 3 April 2006, available on http://www.mod.uk/DefenceInternet/DefenceNews/DefencePolicyAndBusiness/ReidAddressesRusiOn20thcent uryRules21stcenturyConflict.htm.

${ }^{50}$ Attorney General of the UK, supra, n.2; Jay Bybee "Authority of the President Under Domestic and International Law to Use Military Force Against Iraq" Memorandum Opinion for the Counsel to the President, 23 October 2002, 45; Anthony Arend "International Law and the Preemptive Use of Military Force" 26 Washington Quarterly 89 (2003), pp.97-98; Daniel Bethlehem, "International law and the use of force: the law as it is and as it should be", Written evidence submitted by Daniel Bethlehem QC, Select Committee on Foreign Affairs - Minutes of Evidence, June 2004; Philippe Sands "International Law and the Use of Force", 1 June 2004, Written evidence submitted by Professor Philippe Sands QC, to Select Committee on Foreign Affairs, para.15.

${ }^{51}$ For an examination of attempts to reach a definition, see Ben Saul "Attempts to Define "Terrorism" in International Law" 52 Netherlands International Law Review (2005) 57 ; this debate is longstanding, see Thomas Franck and Bert Lockwood, "Preliminary Thoughts towards an International Convention on Terrorism" 68 American Journal of International Law (1974) 69.

${ }^{52}$ This is a subject of debate which has been examined in length in recent years, and will not be addressed in any further detail here. See Noam Lubell, Extraterritorial Use of Force Against Non-State Actors (Oxford University Press, 2010), ch.1-3.
} 
how the nature of the attacking entity might affect the requirement of imminence. The challenge posed in the context of imminence is that, in effect, we are faced with a threat, for which we cannot positively identify how soon it might happen, where it will originate from, where it will strike, or even who precisely will be behind the attack. It is, as such, as far from a specific impending attack as can be. The threat of terrorism plays on the fear of the unknown, and raises the question of engaging in self-defence to prevent a possible future attack without knowledge of what it might be. As such, it challenges not so much the interpretation of imminence, but in effect calls into question the very existence of the imminence requirement. The notion of imminence, as examined earlier, is built around the need to respond with urgency to a concrete and known threat that, absent immediate action, is going to materialise into a specific and identifiable attack. ${ }^{53}$ The idea of acting to prevent a vague and non-specific threat cannot, therefore, be covered within the concept of imminence. ${ }^{54}$ This may lead some to consider rethinking the viability of the imminence criterion as we know it, and to allow states to act even if the threshold of imminence is not met; opinions along this line were emerging most clearly following the September 11 attacks. ${ }^{55}$ Allowing resort to force against vague and non-specific threats is however considered by many to risk ushering in a new age of widespread unwarranted force on the pretext of self-defence, and this approach has failed to gain significant support, with the majority of opinion continuing to consider the possibility of anticipatory self-defence only in relation to imminent attacks. ${ }^{56}$ The notion of imminence presents a brick wall through which claims of self-defence against non-specific and unidentifiable threats cannot pass. Either such claims of self-defence must fail, or the requirement of imminence must be set aside.

It may, on the other hand, be the case that there is concrete information of a specific impending terrorist attack from an identifiable source, in a manner that is similar to the claim of an imminent attack from another state. In such circumstances, the notion of imminence must be understood and applied as it is with impending attacks by another state. This approach is, however, predicated on an assumption that self-defence against non-state actors is a legitimate concept, and would be subject to any additional constraints placed upon such action (such as the need for the defending state to satisfy the necessity requirement by first

\footnotetext{
${ }^{53}$ See previous section on meaning of imminence.

${ }^{54}$ Supra, n.32-34, and accompanying text.

55 Supra, n.48-50.

${ }^{56}$ See discussion in previous sections.
} 
allowing for the territorial state to prevent the attack). ${ }^{57}$ All this is not without further controversy, but as for the question at hand, it means that the threat of terrorism with regard to identifiable specific impending attacks, does not require us to rethink the notion of imminence.

It would appear therefore, that the threat of terrorism does not modify the imminence requirement. In the case of specific and identifiable impending attacks it leaves the concept of imminence intact. Conversely, in the face of unknown, non-specific, future threats, unless we are willing to simply do away with the imminence requirement, the lack of imminence will prohibit a claim of self-defence.

The threat posed by weapons of mass destruction is of a different nature: it is less about the source of the threat, and more about the gravity of its consequences should it materialise. Accordingly, it requires an examination of whether the scale of the threat might affect the understanding of imminence. Even outside the question of WMD, it is clear that the scale of threat must be relevant to imminence, insofar as there must be a minimal threshold to be crossed before one can consider anticipatory self-defence. Such a threshold also goes beyond the question of imminence, and is in fact part of the broader question of the scale of attack necessary to trigger self-defence. Moreover, this is not just a matter of anticipatory selfdefence, and is an issue which is debated with regards to armed attacks more generally. Without straying too far beyond the remit of the current examination, it should briefly be noted that there must exist a certain gravity to the armed attack which can trigger selfdefence. Whether this should include any and all casualties or damage from cross border force, or go beyond what some call mere 'border incidents', remains a subject of debate. ${ }^{58}$ The discussion also tends to centre upon self-defence in response to attacks which have occurred, rather than anticipatory self-defence. With regard to the latter circumstances, any claim to engage in anticipatory self-defence must surely require that the impending attack be at least of a similar scale to an actual attack which would have triggered self-defence. Indeed, in the context of anticipatory action, it may be wise to ensure that this threshold is interpreted

\footnotetext{
${ }^{57}$ Lubell, supra, n.52, ch.2.

${ }^{58}$ For differing views and analysis of the issue of a threshold for armed attack, see: Kunz, supra, n.5, p.878; ICJ Oil Platforms (Islamic Republic of Iran v. United States of America) Reports 1993, p.35, paras. 71-72; EritreaEthiopia Claims Commission, Partial Award Ius ad Bellum, Ethiopia's Claims 1-8, 45 International Legal Materials 430 (2006), para.11; Antonio Cassese, International Law (Oxford, Oxford University Press, 2005), p.354, p.469; Albrecht Randelzhofer "Article 51" in Bruno Simma, (ed.) The Charter of the United Nations, A Commentary (Oxford: Oxford University Press, 1994) pp.661-678, p.669; James Green The International Court of Justice and Self-Defence in International Law (Oxford: Hart, 2009) pp.31-42; Dinstein, supra, n.43, pp.210212.
} 
as being above minor incidents. If one accepts a high threshold of gravity for armed attacks in regular (that is non-anticipatory) self-defence then clearly an equally high threshold is required for anticipatory action. If, however, one considers minor incidents (such as border incidents with few casualties or damage) as constituting armed attacks, it may be prudent to refrain from taking the same position for anticipatory self-defence. This would mean creating a differentiation between the armed attack thresholds of gravity for triggering regular selfdefence as opposed to anticipatory self-defence, with the latter being higher. No doubt this would be a contestable approach, but if we seek to keep anticipatory self-defence from becoming a pretext for unwarranted engagement in force, there may be merit in such an interpretation.

Support for a comparatively high threshold of gravity in the case of impending attacks capable of triggering anticipatory self-defence, can be found in the language often used when discussing the possibility of anticipatory action. The attack which must be thwarted is described using terms such as "an overpowering attack", 59 "a devastating (perhaps a fatal) blow", ${ }^{60}$ or "potentially devastating consequences". ${ }^{61}$ Accordingly, discussion of anticipatory self-defence often presumes a significantly high threshold of gravity for the attack that must be thwarted. Returning to WMD, the threat of such an attack is often raised as a justification to expand the notion of anticipatory self-defence. However, this argument could equally be turned on its head and, in light of the above, the threat of WMD can be presented as part of an approach which in fact restricts the resort to anticipatory action, rather than expands it. The above quotations all share an apparent need to bolster the support for anticipatory selfdefence, with the use of circumstances in which there is an especially high level of threat, rather than referring to any armed attack. Circumstances of WMD attacks could therefore be presented not as evidence for a new expanded form of anticipatory self-defence, but rather as indicating the gravity of threat required for any anticipatory action. ${ }^{62}$ Accordingly, one might argue that anticipatory self-defence, unlike 'regular' self-defence, requires a particularly high threshold of anticipated attack, such as the potentially devastating repercussions of WMD or

\footnotetext{
${ }^{59}$ Franck, supra, n.17, p.107

${ }^{60}$ Dinstein, supra, n.43, p.204

${ }^{61}$ Rosalyn Higgins, Problems and Process: International Law and How We Use It (Oxford University Press, 1994) p.242.

${ }^{62}$ Interestingly, following an examination of the issue of anticipatory self-defence, the UK Foreign Affairs Committee stated the following "We recommend that in its response to this Report the Government set out how, in the event of the legitimisation of the doctrine of anticipatory self-defence, it will persuade its allies to limit the use of the doctrine to a "threat of catastrophic attack"'" House of Commons, Foreign Affairs Committee, Foreign Policy Aspects of the War against Terrorism, Seventh Report of Session 2003-04, Volume I, HC 441-I, Published on 29 July 2004, para.429.
} 
near-existential threats. Accepting this interpretation would mean that absent an imminent threat bearing extreme consequences, anticipatory self-defence would not be justified.

Nonetheless, if an approach of this type is not pursued, and if the legitimacy of anticipatory self-defence is not dependent on a relatively high threshold, then the threat of WMD will present an additional challenge that goes beyond other lesser threats. Indeed, the threat of WMD has instigated a call for rethinking notions of self-defence. It has been noted by a growing number of commentators, that the gravity of the threat must be one of the factors to be considered when assessing imminence of a threatened attack. ${ }^{63}$ While this statement attracts support for its seemingly realistic approach, precisely how this factor of gravity will in fact affect the imminence, is not always clear. The following analysis will attempt to discern the modalities by which the threat of WMD might cause imminence to be assessed differently, and what such an effect would - and would not - justify in practice.

'New tests' of imminence will inevitably mean applying a less strict standard than the one thus far regarded as commonly accepted. ${ }^{64}$ In practical terms, raising the possibility of gravity as an influence on the imminence assessment is designed to allow for a looser interpretation of imminence than perhaps previously endorsed. Accordingly, a question posed by the threat of WMD is whether we might also have a sliding scale of gravity which could affect the interpretation of imminence. Such a link would entail a negative correlation between gravity and imminence, whereby the higher the gravity of the impending attack grows, the weaker the requirement of imminence becomes. Accordingly, when faced with an anticipated threat of attack by WMD, one might argue that imminence be interpreted in a loose manner, allowing for action to be taken in circumstances that might not have allowed for it had the threat been of lesser gravity. There are, however, a number of difficulties with accepting a more lenient version of imminence in the face of WMD. First and foremost, there is the near impossible task of negotiating a sliding scale of imminence. Imminence, as described earlier, often centres upon the notion that an event is impending, and is about to happen any moment in the immediate future. How does one 'relax' the concept of imminence? There are a number of ways to approach this task. The first would require loosening of the temporal 'impending' aspect, by saying that with regard to WMD, imminence should not be understood as demanding that the threat be impending, and opening up a wider temporal framework with no

\footnotetext{
${ }^{63}$ Chatham House Principles, supra, n.24, p.967; Memorandum, supra, n.50, 45.

${ }^{64}$ Greenwood, for example, speaks of "a more generous notion of imminence if what is threatened is another '9/11' rather than the minor acts of the Caroline incident", supra, n.24.
} 
regard to the immediacy of the threat. If this means allowing for self-defence against future attacks with no reference whatsoever to the timescale in which it might materialise, then we would not so much be relaxing the requirement of imminence, but rather would be consigning it to oblivion. ${ }^{65}$ This approach can, however, take a more nuanced form which requires examination, and which can be referred to as 'the last window of opportunity' in which the self-defence will still be effective. ${ }^{66}$ Capability and/or intent of the enemy have also been raised as relevant factors in this context. ${ }^{67}$ Nonetheless, the question remains as to what is the precise event that must be stopped in this last window: is it the acquisition of WMD by an enemy, must there be evidence that this enemy plans to attack, should a specific attack already be in preparation, is a general animosity enough to presume intent, or is it simply the last moment it is physically possible to successfully attack and destroy the enemy's WMD capability?

These questions have been put to the test in a series of cases, ranging from the Cuban missile crisis through to current discussion of potential attacks by Israel/US against Iranian nuclear facilities. In the case of the former, although President Kennedy spoke of a threat to the peace, ${ }^{68}$ and a general sense of threat may have been in place, there did not appear to be any specific attack which would have supported action in self-defence. ${ }^{69}$ Israel justified its attack on Iraq's Osirak nuclear facility in 1981 as a case of self-defence, and that it had attacked at this point in time, since waiting would have made it too late due to the repercussions of attacking a functional reactor. ${ }^{70}$ Israel's operation was however strongly condemned, and was not accepted as a legitimate self-defence action. ${ }^{71}$ Notably it was, among other factors, precisely the lack of imminence that set this operation as one outside the parameters of selfdefence. ${ }^{72}$ An attack by Israel in 2007 against a suspected nuclear facility in Syria received far less attention, ${ }^{73}$ the lack of which can be attributed to a number of factors, ${ }^{74}$ but which

\footnotetext{
${ }^{65}$ As was seen in the above discussion on responding to non-imminent threat in the context of terrorism.

${ }^{66}$ For discussion of this or similar approaches: Memorandum, supra, n.50, 47; Thomas Anderson, "Legitimizing the New Imminence: Bridging the Gap Between the Just War and the Bush Doctrine" 8 Georgetown Journal of Law and Public Policy 261 (2010), pp.278; Arend supra, n.50, p.98; Michael Schmitt, "Counter-Terrorism and the Use of Force in International Law" The Marshall Center Papers, No. 5, 2002 (The George C. Marshall European Center for Security Studies), p.65.

${ }^{67}$ Memorandum, supra, n.50; Chatham House Principles, supra, n.24, p.967.

68 John F. Kennedy, 'Soviet Missiles in Cuba', Department of State Bulletin, November 12, 1962, pp. 715-720.

${ }^{69}$ See discussion in Dinstein, supra, n.43, p.199; see also Ruys supra, n.24, pp. 267-272.

${ }^{70}$ UN Doc. S/PV.2280, 12 June, 1981, paras.58, 95.

${ }^{71}$ S/RES/487 (1981), 19 June 1981.

72 See UK statement, supra, n. 19.

73 "Israelis 'blew apart Syrian nuclear cache", The Sunday Times, 16 September 2007.

${ }^{74}$ Including Syria's own desire to avoid scrutiny over the construction of the facility, and the relative low damage caused by the strike.
} 
makes it difficult to draw any conclusive evidence of legal opinion. With ongoing speculation about the possibility that the US/Israel might strike Iranian nuclear facilities, ${ }^{75}$ the debates over action of this type will not be dissipating anytime soon.

There are a number of serious obstacles to accepting the legality of self-defence in circumstances such as these. First, and most obvious, is the absence of a specific attack that must be thwarted, no matter how far into the future one is willing to look. General animosity and political rhetoric may well be disconcerting, but they are hardly evidence of an identifiable attack that must be stopped in its tracks. More is required in order to satisfy even the lowest of evidentiary thresholds. ${ }^{76}$ The attack on the Iraqi reactor was therefore widely recognised as unlawful, ${ }^{77}$ and an attack against Iran in similar circumstances is likely to elicit the same criticism. Second, these circumstances revolved around the threat of an attack at a future date, possibly years into the future. The further ahead we advance on the temporal scale, the more possibilities there are for reality to diverge from the predictions. When the impending attack is hours, days or perhaps even weeks away, the amount of variables that might change and cause the prediction to be faulty are far fewer than in the case of an attack that is alleged will materialise three years later. Nonetheless, a possibility might be raised of a high likelihood of a specific attack that will occur further into the future, and that it is not possible to wait until the last minute when it would become imminent (that is now is the 'last window of opportunity'). In such circumstances, despite the fact that this scenario might fall foul of the imminence requirement, might it be legitimately argued that self-defence at this early stage is nevertheless necessary? Such an argument is theoretically possible, but unlikely to hold in practice. First, it could be argued that imminence is a requirement additional to necessity. While non-anticipatory self-defence requires necessity and proportionality, ${ }^{78}$ the very notion of anticipatory self-defence was developed in the context of imminent attacks, and the requirement of imminence may have become a third, additional, criterion. ${ }^{79}$ Any such argument would therefore have to reinvent the understanding of imminence. Second, the premise itself is flawed when considering scenarios far into the future, as the infinite possibilities for unforeseen developments, including the prospects of preventing the materialisation of the threat through other, non-forcible, avenues, will mean that the accuracy

\footnotetext{
75 "Netanyahu: Israel has right to pre-emptive attack on Iran" The Independent, 6 March 2012.

${ }^{76}$ See below section on proof.

${ }^{77}$ Resolution, supra, n.71; Franck, supra, n.17.

${ }^{78}$ Advisory Opinion on the Legality of the Threat or Use of Nuclear Weapons (8 July 1996), [1996] I.C.J. Rep., para.41.

${ }^{79}$ See earlier section on requirement of imminence.
} 
of prediction will take a nosedive far below any reasonable threshold that could be presented as close to certain. It would then mean arguing that it is necessary to use force right now to prevent an event that may well never happen, and no possibility to credibly make this assessment. ${ }^{80}$ The two key elements of imminence are linked: the further we venture into the future and away from 'impending', the less possible it becomes to identify a specific threatened attack as opposed to a vague concern over the possibility. As such, the lack of imminence will most likely deliver a fatal blow to the credibility of an argument based on necessity. The imminence criterion cannot be met in the context of desiring to prevent the acquisition or development of WMD in order to negate the potential that they might, or might not, be used at an indeterminate date in the far future. Arguing that imminence can be understood as allowing a right to use force in circumstances where there is no evidence of a specific attack in the foreseeable future, is in fact no more than paying lip-service to the imminence criterion while bending it so far out of shape it becomes unrecognisable. It would be more coherent an approach to simply advocate the removal of the imminence requirement altogether, and either develop new ways to keep anticipatory self-defence within safe bounds, or be prepared for the dangerous consequences of a less-restrictive approach to use of force.

Finally, there is however one more option that might be taken with regard to a possible new approach to imminence in light of WMD. While maintaining the insistence that imminence requires that there be a specific impending attack we are seeking to prevent, we might nevertheless allow in certain circumstances, such as WMD threats, for variance in the accepted level of likelihood of the attack materialising. It must still centre upon a threat of a specific impending attack to be thwarted, but given the higher risk posed by this type of attack, one might argue for a less stringent demand for absolute certainty that it will occur. ${ }^{81}$ Once again, such an approach is likely to be highly controversial, as it opens the door towards an acceptance of anticipatory self-defence and use of force in circumstances in which it is uncertain whether the threat was ever really going to materialise. As such, it would appear to negate the very premise of anticipatory self-defence as a necessary course of action in the face of an incoming attack. Anticipatory self-defence, it can been argued, should be limited only to those circumstances in which we are certain of the imminent attack, and losing our grip on this certainty leads down a dangerous path of use of force based on nothing but

\footnotetext{
80 "[i]mminence provides an objective yardstick against which the necessity of private force can be measured...", Bakircioglu, supra, n.9, p.213.

${ }^{81}$ For example, see the reference to balancing low probability against a high degree of harm, in Memorandum, supra, n.50, 47.
} 
speculation. This criticism reflects a sound approach, requiring definitive notions of certainty as a safeguard from abuse of the law. But it also opens up room for another question: what does certainty mean in this context, and is it ever appropriate to claim that an imminent attack is certain to happen?

\section{Certainty}

Centuries ago, Grotius cautioned that "to maintain that the bare probability of some remote, or future annoyance from a neighbouring state affords a just ground of hostile aggression, is a doctrine repugnant to every principle of equity." 82 Indeed, the idea of going to war on the basis of probabilities is one that likely continues to appear repugnant to many up to this day. Probabilities are, however, the only reality we can realistically work with, despite any inclinations to fall under the alluring spell of illusions of certainty. Definitive language is commonly used with an assumption that we can require certainty as a categorical and unwavering test, rather than realising the fluid and indeterminate challenge posed by such a requirement. Simply put, as long as we are talking about an attack that has not yet happened and this is the essence of anticipatory self-defence - then we can never be certain of its future materialisation. Troops marching towards a border can be ordered to turn back; missiles being loaded might not be fired; and orders to carry out attacks can be rescinded in the final moment before an attack takes place. In fact, unless states (or individuals) are claiming the clairvoyant powers to predict the future, the one thing they can never do, is claim that a future attack is certain. We are, therefore, left playing the game of probabilities and trying to settle upon a notion of being 'certain enough' that an attack is imminent. If that is the case, a serious investigation of the required certainty of an imminent attack, necessitates a better understanding of the relationship between certainly, likelihood, and decision making processes. Judgment in the face of uncertainty is a daily necessity cutting across all paths of life and all areas of policy, ranging from medical decisions, criminal law convictions, economic policy, and more. ${ }^{83}$ Rarely are we afforded the luxury of making a decision with all the facts pertaining not only to the past but also the future. To combat uncertainty, a number of principles can be employed to assist the decision making process. The starting point is an assumption that the government of a state is presented with information concerning a possible attack against them from another state, and assuming also that other options have been

\footnotetext{
${ }^{82}$ Grotius, supra, n.1, Book II, Chapter 1, XVII.

${ }^{83}$ For a detailed analysis of the notion of uncertainty in decision making, see Kenneth Hammond Human Judgment and Social Policy: Irreducible Uncertainty, Inevitable Error, Unavoidable Injustice (Oxford University Press 1996).
} 
explored, so that the only way to avoid being struck by such an attack, would be to engage in anticipatory self-defence. To justify such action, the feared attack must be imminent. However, there can be no fool-proof certainty that this impending attack will indeed happen. The decision makers at the head of government will therefore, whether they realise it or not, be engaging in a process of statistical analysis, balancing values, probabilities, risk, and the law. Much of this can be encapsulated in a model which lays bare the consequences of false positives and false negatives. ${ }^{84}$ If the question is whether there really is an imminent attack approaching, then false positives are decisions which proceed on the basis of an imminent attack which in fact would not have happened, whereas false negatives would be decisions to erroneously assume there is no imminent attack that requires immediate action and neglect to thwart it. Each of these has its consequences: false positives will lead to unnecessary use of force by the state, resulting in casualties and damage, increasing the chances of further escalation of conflict, and carrying potential repercussions in terms of international politics and the perceived disregard for international law. Conversely, false negatives would mean failing to act and suffering an attack against the state, with the casualties and damage that this may entail. A simplistic assessment would rely on the 'duality of error' approach, choosing between the lesser of two evils - would we rather be wrong and endure a false positive, or a false negative. ${ }^{85}$ The balance in this case may well shift toward preferring false positives on the basis of perceived self-interest, since this would mean that any unnecessary casualties will mount up higher on the other side of the border, rather than risking being seen as falling asleep on guard and allowing an attack to proceed on home soil. But such an appraisal would ignore the additional ramifications that may come from engaging in an unnecessary attack, including the human, political, and legal costs. More importantly, this would be an overly simplified analysis, which treats the likelihood of false positives and false negatives as being equal. A better reasoned decision would need to include some measurement of probabilities for each of the possible outcomes - if a false positive is far more likely than a false negative, then this could tilt the balance. Furthermore, in the choice between false negatives and false

\footnotetext{
${ }^{84}$ For an analysis combining fields of psychology and policy decisions in this context, see Philip Dunwoody \& Kenneth Hammond "The Policy of Preemption and Its Consequences: Iraq and Beyond" 12 Journal of Peace Psychology (2006) 19. The authors use Brunswik's lens model and the Taylor-Russell diagram, to analyse the decision making process on the topic of preemptive military action; for general discussion of false positives and negatives, see Hammond, ibid, ch.1.

85 One of the first and most well-known examples is known as 'Pascal's Wager' in which the $17^{\text {th }}$ Century French philosopher and mathematician, queried whether one would be safer in believing there is a god even if that might be incorrect, or living as if there is no god, and the risks entailed if this were false. See Hammond on this and for an examination of duality of error and how this affects decision making across a number of fields. supra $\mathrm{n} .83$, ch.1-2.
} 
positives, the risk calculation will include consideration of the specific details of the perceived threat.

This is the point at which the earlier discussion of WMD may become relevant. A decision resulting in a false negative would mean incorrectly assuming that the circumstances do not amount to an imminent attack requiring anticipatory action and as a result, suffering the consequences of an attack that might have been prevented. If these consequences entail being subjected to a nuclear attack, then the repercussions of a false negative will leap to the top of the scale. The risks of a false positive might, at this point, be seen as a more palatable outcome despite its own repercussions. ${ }^{86}$ In other words, once we acknowledge that any decisions on imminent attacks will inherently include a need to predict the likelihood of an uncertain event, we must also accept that this necessitates engaging in a decision making process that is not a precise science, and which can be affected by the variables of the formula. The potential devastation caused by a WMD attack is one such variable. The need to make a judgement within a realm of uncertainty could, therefore, mean that the higher perception of risk calls for the toleration of a lower level of certainty. This lower threshold of certainty could manifest in one of two ways: first, it might affect the level of evidence on the basis of which the decision is made (the 'decision criterion') ${ }^{87}$ As much as we might wish it to be so, there will never be $100 \%$ certainty in assessing future events. Therefore, if, for example, for a non-WMD case the state might only have engaged in anticipatory self-defence when they are $95 \%$ certain that a specific enemy attack is imminent, when faced with WMD they might decide to move ahead when they are $80 \%$ certain, as a result of the higher projected damage entailed by false negative decisions. Second, since the accuracy of assessing likelihood of a specific threat materialising will diminish the further it is into the future, the temporal aspect of imminence could also be affected. Lowering the threshold of certainty, would result in allowing for consideration of thwarting attacks that are less certain to happen since they are expected to occur slightly further down the line. However, the temporal scale can be traversed only so far. If, in the circumstances of the case, the timeframe opens up the realistic possibility for preventing the attack by other means, then the necessity requirement is less likely to be satisfied. Moreover, as the earlier analysis demonstrated, advancing along the temporal scale not only reduces the likelihood of a future attack, it also makes it more and more difficult to credibly claim that there are plans for a specific attack

\footnotetext{
86 "The greater the threat, the greater is the risk of inaction" National Security Strategy of the US, supra, n.48. p.15.

${ }^{87}$ See the following section on proof.
} 
rather than vague fear of a threat. In the latter circumstances, this is no longer just a question of a reduced certainty as to whether the attack will happen, but it becomes a situation in which there is no specific attack to be thwarted, and is therefore removed from the realm of justification through imminence.

Accordingly, if we are to perceive anticipatory self-defence as a legitimate course of action taken to prevent an imminent attack, it may be unavoidable that faced with information about a possible specific attack by way of WMD, decision makers will be more likely to engage in anticipatory self-defence, than when they are faced with a lesser gravity of repercussion for inaction. Lastly, it should be stressed that the above decision-making process must be restricted to those cases, in which the possible attack over which self-defence is contemplated, is specific and identifiable; this is not an open door to justifying self-defence against vague concerns over acquisition of WMD or fear of attack due to general animosity between nations.

\section{Proving the existence of an imminent attack}

Assessing the likelihood of an imminent attack will rest on the use of reliable evidence. Indeed, it has been noted that "evidence, rather than abstract principle, seems to determine the response to each instance in which a state claims the right to use force in anticipatory selfdefense." 88 Proving the existence of an imminent attack will therefore require evidence; this inevitably requires a decision that a given amount of evidence be regarded as constituting sufficient grounds for assuming that the prediction is correct. This factor regarding the required level of evidence can be described as the "decision criterion". ${ }^{89}$ This choice of threshold for considering that the evidence is sufficient will have a direct effect on the balance between correct decisions and disastrous mistakes: "[g]iven a particular level of uncertainty, reducing false negatives by lowering the decision criteria must increase false positives and vice versa". ${ }^{90}$ In other words, a high threshold for level of evidence would lead to fewer unwarranted uses of force (false positives), but raise the risk of inaction due to insufficient proof of an imminent attack that does materialise (false negatives). Conversely, a lower threshold of evidence would more easily allow for use of force and therefore reduce chances of negligent inaction (false negatives), but increase the chance of unnecessary force

\footnotetext{
${ }^{88}$ Franck, supra, n.17, p.107; Indeed, such an approach echoes the words of Vattel who spoke of the need to provide proof, so as to justify action in the eyes of all mankind. Vattel Chap. XVIII. Of The Mode of Terminating Disputes Between Nations, 334

${ }^{89}$ Dunwoody and Hammond, supra, n.84, p.26.

${ }^{90}$ Ibid.
} 
(false positives). The understanding of what might constitute acceptable proof of an imminent attack is therefore a crucial concern.

There has been relatively little attention to discerning the type of evidence that would be considered sufficient for such purposes. ${ }^{91}$ It is said that evidence to support the use of force must be objective, and "clear and convincing". ${ }^{92}$ The reliability of the evidence will be a crucial matter. ${ }^{93}$ Examining Uganda's claim to self-defence, the ICJ rejected unsupported internal political reports, ${ }^{94}$ statements by Ugandan politicians, ${ }^{95}$ "news reports of variable reliability" 96 and "internal documents, often with no authenticating features, and containing unsigned, unauthenticated and sometimes illegible witness statements." ${ }^{97}$ Moreover, proving an imminent attack creates particular difficulties as it will, as discussed earlier, require an element of prediction. In the context of self-defence, a state cannot rely on "supposed intention,"98 "assumptions, expectations or fear of what is sometimes called a 'latent' threat," 99 nor mere propensities of another state. ${ }^{100}$ The Fact-Finding Mission to the conflict in Georgia was of the view that the presence of Russian troops near the Georgian border may have indicated an abstract danger, but there was "not enough evidence to ascertain such an imminent attack by Russia." 101

Ultimately, when dealing with assessing an imminent event (as opposed to a past occurrence), the judgment of evidence will include a measure of subjectivity and reliance on a combination of factors some of which are more susceptible to fault than others (e.g. opinions provided by intelligence analysts). ${ }^{102}$ It is virtually impossible to define an objective

\footnotetext{
${ }^{91}$ Among the few related examples is an examination of the evidence necessary in the context of self-defence against terrorism, in Mary Ellen O'Connell, "Evidence of Terror" 7 Journal of Conflict and Security Law (2002)19; For an examination of the ICJ's 'gathering, evaluation and disposition of evidentiary material' see Keith Highet, "Evidence, the Court, and the Nicaragua Case" 81 American Journal of International Law (1987)1 .

92 "The alternatives to the clear and convincing standard include standards both lower and higher than clear and convincing. Lower standard requires only a preponderance of the evidence; the higher standard mandates proof beyond a reasonable doubt." O'Connell (but note that this was said in a different context), ibid.

93 ICJ DRC Uganda para.120.

${ }^{94}$ Ibid, paras.122,123.

${ }^{95}$ Ibid, paras. 124,129.

${ }^{96}$ Ibid, para. 136.

${ }^{97}$ Ibid, para. 134 .

${ }^{98}$ Grotius, supra, n.1, Book II, Chapter 1, V.

${ }^{99}$ Dinstein, supra, n.43, p.206

100 "Propensities, however, are obdurately unamenable to conclusive proof." Franck, supra, n.17, pp.106-107.

${ }^{101}$ Fact-Finding Mission on Georgia, supra, n. 14, 254-256.

102 "All of the best satellite imagery, electronic interception, and human intelligence afforded by modern technology does not change the basic fact that at the end of the day some analyst somewhere has to make a guess about what an adversary is doing. Sophisticated technology makes that guess a highly educated one, but a
} 
watertight definition of proof for future attacks. Each case will be examined in light of a different combination of varying indicators, and the determination may well be influenced by subjective interpretation of the eyes who behold them. If we are to reduce the risk of unnecessary force while allowing anticipatory self-defence, then we must require that the evidentiary threshold be as stringent as possible. But, such an approach can only be taken if accepting that this also carries its own risks of failing to act, due to the high evidentiary threshold, against attacks which would materialise. The acceptance of risks is a necessary result of engaging with uncertainty. Ultimately, we are dealing with "threat assessment based on the integration of multiple fallible indicators under conditions of irreducible uncertainty."103

\section{Conclusion}

The question of whether or not a particular attack is imminent will never be able to generate the same level of agreement as cases in which the armed attack has already occurred. Controversy will almost always follow use of self-defence in this context. However, an examination of the concept of imminence in relation to self-defence does reveal certain characteristics that must be satisfied for an attack to be imminent: it must be an impending attack over which there is a reasonable level of certainty that will occur in the foreseeable future; and it must be a specific and identifiable attack, rather than a vague threat of unknown form. A majority of opinion supports this notion of imminence. Although this understanding has been questioned in light of modern threats, it remains largely unchanged. Accommodating the arguments made over the threat of unpredictable terrorism, could mean relinquishing the notion of imminence, and allowing for self-defence against vague unknown threats in a manner that renders the concept of self-defence open to unconscionable abuse. As for the concern over attacks by WMD, it has been demonstrated that the gravity of the perceived threat might understandably influence the decision-making process in relation to the level of certainty to be demanded, but that this must be kept within the strict confines of a threat of a specific attack. Moreover, there will remain a threshold of evidence to be met in order to establish the existence of the threat. While the threat of WMD has also led to some calls for flexibility on the temporal element so as to counter attacks further into the future, the danger is that in practice this would lead to allowing self-defence not only against non-

guess it remains." Anderson, supra, n.66, p.282; "assessments are inherently subjective and contextual" Schmitt, supra, n.66, p.69; views of evidence can change with time Franck, supra, n.17, p.106-7.

${ }^{103}$ Dunwoody \& Hammond, supra, n.84, p.23-24. 
temporally impending attacks, but also against unspecified future threats based on fear and suspicion rather than evidence. The wider temporal framework might also mean that other, non-forcible, options are available. For both these reasons, the temporal scale cannot be stretched if it results not only in negating the imminence criterion, but also in discrediting any argument of necessity. Bearing this in mind, the analysis of decision making in the face of uncertainty has revealed that the potential devastation via attack of WMD might allow for a slight shift away from demanding that the threatened attack be immediate. However, this cannot allow for ignoring non-forcible viable alternatives, and it cannot go beyond the reasonably foreseeable future in a manner which transitions from thwarting a specific approaching attack into action to prevent a generalised threat.

Ultimately, the only way to completely avoid these dilemmas is to take a position that precludes variable standards of proof, probability assessments, and risk calculation, by demanding absolute certainty as a prerequisite for anticipatory action. The flaw in such an approach is that, as presented earlier, certainty of a future event is simply impossible. If it is absolute certainty of an attack that we require, then the attack would not be an imminent future event, but rather a present occurrence. As such, the concept of imminence would not be relevant, and self-defence would rule out anticipatory action. Clearly, therefore, one possibility is to reject the legitimacy of anticipatory self-defence, and thereby avoid the challenges in applying the criterion of imminence. Another option is to reject the imminence criterion, and allow for use of force against non-specific threats further into the future. This opens the door to a dangerous new world of preventive self-defence against vague threats, and can lead to abuse of the notion of self-defence on a massive scale. If, however, our wish is to maintain a position that endorses anticipatory self-defence while limiting it to absolute emergencies, then it is precisely the criterion of imminence, with all the challenges addressed above, that serves as the strongest barrier to an expansive notion of preventive operations, while allowing anticipatory self-defence in those circumstances in which it is more likely to be viewed as an appropriate course of action. 